\title{
Occurrence and distribution of ochratoxin A- producing fungi during post-harvest process of cocoa (Theobroma cacao L.)
}

Elena Isabel Champion-Martínez

Tecnologico Nacional de Mexico

Oscar González-Ríos

Tecnológico Nacional de México: Tecnologico Nacional de Mexico

Durand Noël

CIRAD

Jean-Christophe Meile

CIRAD

Francisco José Fernández

Universidad Autonoma de la Ciudad de Mexico

Pascaline Alter

CIRAD

Didier Montet

CIRAD

Mirna Leonor Suarez-Quiroz ( $\nabla$ mirna.sq@veracruz.tecnm.mx )

Tecnológico Nacional de México: Instituto Tecnologico de Veracruz https://orcid.org/0000-0003-31713663

\section{Research Article}

Keywords: Aspergillus, cocoa, fungi, Ochratoxin A, PCR, post-harvest.

Posted Date: June 7th, 2021

DOI: https://doi.org/10.21203/rs.3.rs-359498/v1

License: (c) (i) This work is licensed under a Creative Commons Attribution 4.0 International License.

Read Full License 


\section{Abstract}

The occurrence of ochratoxin A (OTA) and OTA-producing fungi in cocoa beans has been previously reported to be linked to harvest and post-harvest treatment conditions. The aim of this study was to identify OTA-producing fungi during harvest, fermentation, drying and storage of cocoa beans from two farms located in the most important cocoa-producing region in Mexico, and their relationship with OTA levels of contamination. A high contamination of ochratoxigenic fungi was observed in drying $(78.4 \% \pm$ $13.6)$ and storage $(70.3 \% \pm 3.2)$ steps of cocoa samples from farm A. In farm $B$, the wash step of cocoa beans after fermentation reduced pulp residues and consequently the OTA-producing fungi infection during drying $(12.7 \% \pm 5.8)$ and storage $(37 \% \pm 10.4)$ steps were diminished. The main OTA-producing strain isolated from Malt Extract Agar (MEA) growth medium was Aspergillus carbonarius (14307.5 $\mu \mathrm{g} / \mathrm{kg}$ ). The presence of ochratoxigenic species was correlated to high levels of OTA measured in cocoa beans during storage in both farm $A$ and $B(304.6 \pm 15.3$ and $11.3 \pm 0.5 \mu \mathrm{g} / \mathrm{kg}$, respectively), and in fresh cocoa beans from farm B $(22.2 \pm 3.5 \mu \mathrm{g} / \mathrm{kg})$. This study reports for the first time OTA content and ochratoxigenic species during cocoa process in Mexico. This allowed the identification and evaluation of the sanitary risks linked to Mexican cocoa production.

\section{Introduction}

The cocoa bean (Theobroma cacao L.) is an important commodity with a great international demand notably because of its use as an ingredient in a large number of foodstuffs (Tafuri et al. 2004). Around $70 \%$ of world cocoa production occurs in the equatorial region of West Africa, and the rest in the equatorial regions of Central and South America, some Caribbean islands and tropical areas of Asia (CAC-Codex Alimentarius Commission 2008).

In America, even if Brazil is positioned as the sixth larger producer of cocoa in the world, Mexico plays an important role as a cocoa producer due to the quality of its production. Mexico appears as a producing country that exports exclusively or partially fine or aroma cocoa (ICA 2011). In 2019, the Cocoa of Excellence Program recognized Mexico as part of the 50 best high quality cocoa bean among 223 cocoa bean samples received from 55 cocoa-producing country participants (ICA 2019). Around 27000 tons of cocoa beans are annually produced in Mexico (SIAP/SAGARPA 2018). The international market is mainly focused on over the cocoa paste. In Mexico, $75 \%$ of the cocoa cultivars are concentrated in the state of Tabasco, with $407820000 \mathrm{~m}^{2}$. Trinitario is the principal cocoa cultivar, resulting as a natural hybrid from Criollo and Forastero seeds (Gonzalez and Amaya 2005). However, some surfaces are exclusively dedicated to Criollo cocoa white bean (clone Carmelo 1) cultivation, which has been awarded in the International Cocoa Awards in 2011 in the category of Fresh fruits in the region of Central America and the Caribbean (ICA 2011). This represents an opportunity for export to Europe, in terms of quality rather than quantity.

Variations in the Cocoa process do exist according to each producing country. In Mexico, the process starts with the pod harvest from cocoa trees, followed by an opening step, which consists of a manual 
release of the cocoa beans from the pods. Cocoa beans are seeds with three main parts: namely testa (seed coat), embryo, and cotyledon (Thompson et al. 2001; Afoakwa 2010). Attached to the testa is the sugary, white mucilaginous pulp (Biehl and Ziegleder 2003). Cocoa pulp content makes it a rich substrate for microbial growth. Therefore, the cocoa pulp is immediately contaminated and degraded by microorganisms naturally presents in the process, resulting in spontaneous fermentation. The fermentation time is about 3 to 5 days. It is performed in wooden boxes with holes drilled in the base to allow aeration and drainage of 'sweetings,' liquids produced from pulp degradation during fermentation. After fermentation, a drying step is carried out to reduce moisture in beans to 6-7\%. Finally, cocoa beans are stored in sacks for transport and trading. However, conditions of cocoa harvest and post-harvest steps are conducted without sanitary control. Therefore contamination by different fungal species during these stages is common and may alter its quality (Magan and Aldred, 2005; Teixeira et al., 2011).

Aspergillus and Penicillium genera are associated with the production of toxic secondary metabolites, such as Ochratoxin A (OTA). In tropical areas OTA is mainly produced by Aspergillus carbonarius, Aspergillus niger and Aspergillus ochraceus and in temperate zones by Penicillium verrucosum and Penicillium nordicum (Abrunhosa et al., 2001; O'Callaghan, Caddick, \& Dobson, 2003; Pitt, 2000; Varga et al., 1996). In humans, OTA has been associated with the Balkan Endemic Nephropathy (Stoev 1998), and to the chronic interstitial nephropathy in Tunisia (Maaroufi et al. 1995). Moreover, it acts as a neurotoxic, immunosuppressive, teratogen and carcinogen compound (Höhler 1998; Pfohl-Leszkowicz and Manderville 2007; Woo and El-Nezami 2016). The International Agency for Research on Cancer (1993) classified OTA within group 2B as a possible carcinogen in humans. This toxin is of particular interest, given their negative effects on human and animal health (Hussein and Brasel 2001; Zain 2011).

Cocoa is one of major commodities frequently contaminated with OTA (Turcotte et al. 2013; Taniwaki et al. 2018). Previous studies attempted to define the diversity of ochratoxigenic fungal species present in cocoa beans during the post-harvest period. Species from genus Aspergillus, as Aspergillus westerdijkiae and A. carbonarius (Amézqueta et al. 2008; Mounjouenpou et al. 2008; Sánchez-Hervás et al. 2008; Copetti et al. 2010) as well as Penicillium genera isolates were detected, but no identification at species level was achieved (Teixeira et al. 2011).

OTA was detected in powder roasted cocoa from Ivory Coast, Guinea, Nigeria and Cameroon, with OTA values over $2 \mu \mathrm{g} / \mathrm{kg}$ in $54.8 \%$ of samples (Bonvehí 2004). However, the level of OTA contamination in cocoa beans from Mexico is unknown. Hence its presence is not controlled nor regulated. This lack of information makes it necessary to study to define the quality of the cocoa bean in terms of safety, and state if any action is required to control the process of Mexican cocoa production.

The aim of this work was to evaluate the occurrence of fungal biota, OTA-producing fungi, and OTA content in cocoa beans from two representative farms in Mexico during the harvest and post-harvest process to establish critical checkpoints. This is the first attempt to study the possible correlation between the presence of ochratoxigenic species and OTA content in Mexican cocoa beans and the production conditions. 


\section{Materials And Methods}

\subsection{Samples}

The samples were collected during the cocoa harvest season in March-May 2013, in two farms (A and B) located in Cárdenas-Tabasco, the most important cocoa-producing region in Mexico. Samples included pods and cocoa beans at different times of fermentation, drying, and storage steps. For every sample, $500 \mathrm{~g}$ of cocoa beans were collected. A total of 28 samples (15 samples from farm A and 13 samples from B) were analyzed.

\subsection{Cocoa processing}

The features of the cocoa process in each of the farms are described as follows:

Farm A: The cocoa variety white bean Criollo is processed in the plant located on the same site. The plantation where the cocoa pods came from is under pests' control. The pods come from a unique plantation, and only the healthy ones (no visible damage from the outside) are processed. The pods opening are realized on the spot within 48 hours after harvest, then approximately one ton of cocoa beans are placed into a wooden box, where fermentation is carried out for five days, including turnings every $24 \mathrm{~h}$. The cocoa beans are then dried on a plastic netting for 9 to 12 days (parabolic drying). Finally, dried cocoa is processed almost immediately to sell it. The remained cocoa is placed in jute sacks and stored at room ambient temperature without aeration or humidity controls (Fig. 1).

Farm B: The cocoa processed is a heterogeneous mixture from diverse varieties and locations. The principal variety used is Forastero. Healthy and damaged pods are processed. Pod opening is carried out outside the processing plant, so the delay between harvest and pod opening varies 24 to $72 \mathrm{~h}$. Then, beans are transported in bags, buckets, and/or plastic bags without cooling conditions until they reach the processing plant, where fermentation is carried out. The cocoa beans are fermented in wooden boxes for three days, with turning every 24 hours. At the end of the fermentation, cocoa beans are washed and dried immediately by spreading over a concrete patio at ambient temperature for four days. Dried cocoa is stored in polypropylene sacks at room temperature with aeration and no humidity levels controlled (Fig. 1).

\subsection{Cocoa sampling Mycological analyses}

The isolation and identification of fungal species associated with cocoa were performed on beans and pod samples. In farm A, one pod from the tree and one harvested pod were used for analyses. As for cocoa beans, one sample from fresh natural beans, five from fermentation, three from drying and four from storage steps were collected for analyses for a total of 15 samples. In farm B, one pod from the tree was considered for analyses. Also, one bean sample from fresh natural beans, four from fermentation, three from drying, and three from storage steps were considered. A total of 12 samples were collected for analysis in Farm B. 
For beans samples, every single bean from each stage in the process was cut into small pieces; 50 pieces were placed in Petri dishes. For pod, thin slices of the shell of similar size were cut and placed in Petri dishes. Samples were plated (without superficial disinfection) directly on Petri dishes, containing dichloran $18 \%$ Glycerol agar (DG18: Glucose $10 \mathrm{~g}$, peptone $5 \mathrm{~g}, \mathrm{KH}_{2} \mathrm{PO}_{4} 1 \mathrm{~g}, \mathrm{MgSO}_{4} .7 \mathrm{H}_{2} \mathrm{O} 0.5 \mathrm{~g}$, agar $15 \mathrm{~g}$, glycerol $220 \mathrm{~g}$, and $1 \mathrm{~mL}$ ethanol $0.2 \%$, chloramphenicol $0.1 \mathrm{~g}$, dichloran $2 \mathrm{mg}$, distilled water QS $1 \mathrm{~L}$ ) (Hocking and Pitt 1980). The study was carried out with 50 particles placed in Petri dishes with duplicates. The plates were incubated at $25^{\circ} \mathrm{C}$ for seven days. Results were expressed as a percentage of particles infected. Taxonomic keys for common food-borne fungi (Samson et al. 2004) were applied to distinguish ochratoxigenic from a non-ochratoxigenic fungus. The fraction of putative ochratoxigenic fungi that could be grown from the cultivated particles was expressed as a percentage of OTA-producing fungi infection.

All strains (putative ochratoxigenic and non-ochratoxigenic) were isolated and sub-cultured on malt extract agar (MEA), and molecular biology techniques confirmed their identity. The putative ochratoxigenic isolates were tested for their ability to produce OTA on MEA medium; the results were expressed in $\mu \mathrm{g} / \mathrm{kg}$ of solid culture medium as described below.

\subsection{Extraction and purification of OTA from the culture medium and cocoa beans}

From fungal culture: isolates identified as putative OTA producers were cultivated in MEA medium at $25^{\circ} \mathrm{C}$ for seven days, spores were harvested from the Petri dish surface with peptone water ( $1 \%$ peptone $0.8 \% \mathrm{NaCl}$ ). Spores concentration was estimated by direct count, by using a counting chamber (Neubauer), the suspensions were adjusted to a final concentration of $10^{6}$ spores/ $\mathrm{mL}$. Aliquots of $5 \mu \mathrm{L}$ were placed at the center of a Petri dish containing MEA and incubated at $25^{\circ} \mathrm{C}$ for seven days, three agar plugs of $5 \mathrm{~mm}$ diameter were removed from each Petri dish, weighed, and introduced into a small vial. OTA was extracted using the procedure described by Bragulat et al. (2001) and modified by Suárez-Quiroz et al. (2004), with $2.5 \mathrm{~mL}$ methanol: formic acid (25:1), for $15 \mathrm{~min}$ in an ultrasonic bath. The solutions were filtered with a $0.45 \mu \mathrm{m}$ microfilter (Milex 25 microfilter, Agilent Technologies). The filtered solution was evaporated at $60^{\circ} \mathrm{C}$ under $\mathrm{N}_{2}$ stream, and the residue was re-dissolved in $1 \mathrm{~mL}$ of the mobile phase $\left(\mathrm{H}_{2} \mathrm{O} /\right.$ acetonitrile/acid acetic, 51:48:1).

From cocoa beans: cocoa samples (with shell) were frozen at $-80^{\circ} \mathrm{C}$, and then $100 \mathrm{~g}$ were ground (Laboratory Mill 3600, Perten). OTA was extracted from $50 \mathrm{~g}$ of ground cocoa with $200 \mathrm{~mL}$ of extraction solvent (acetonitrile/ $\mathrm{H}_{2} \mathrm{O}, 60: 40$ ) and $4 \mathrm{~g}$ of $\mathrm{NaCl}$, then blended for $2 \mathrm{~min}$ at high speed. $48 \mathrm{~mL}$ of homogenized solution were transferred to a Falcon tube and then centrifuged at $10000 \mathrm{xg}$ (Centrifuge Mod. 2K15, Sigma, Germany) for $10 \mathrm{~min}, 4 \mathrm{~mL}$ of the aqueous phase were diluted in $44 \mathrm{~mL}$ of phosphatebuffered saline (PBS) plus Tween $20(0.01 \%)$ and applied to an immuno-affinity column (Ochraprep ${ }^{\circledR}, \mathrm{R}$ Biopharm, France) at a flow rate of $2-3 \mathrm{~mL} / \mathrm{min}$. The column was then washed with PBS ( $20 \mathrm{~mL})$ and OTA eluted with $3 \mathrm{~mL}$ of methanol HPLC grade into an amber vial, a backflush was applied to the last milliliter. The solution was evaporated at $60^{\circ} \mathrm{C}$ under $\mathrm{N}_{2}$ stream, and the dry residue was dissolved in 1 $\mathrm{mL}$ of the mobile phase. 


\subsection{Quantification of OTA}

OTA extracts were analyzed by HPLC with a fluorometric detector (Shimadzu LC-10 ADVP, Japan) with a loop of $100 \mu \mathrm{L}$, a reverse-phase column at $35^{\circ} \mathrm{C}, 1 \mathrm{~mL} / \mathrm{min}$ isocratic flow (mobile phase:

$\mathrm{H}_{2} \mathrm{O}$ /acetonitrile/acetic acid, 51:48:1), wave longitude excitation at $333 \mathrm{~nm}$ and emission at $460 \mathrm{~nm}$. The calibration curve was prepared with an OTA standard (1 $\mu \mathrm{g} / \mathrm{mL}$; ref. PD 226 R. Biopharm Rhone Ltd., Glasgow, UK) (Nakajima et al. 1997). Nine different controls were used for the standard curve construction with solutions containing $0.05,0.075,0.1,0.25,0.5,1,2.5,5$, and $10 \mathrm{ng}$ of OTA per $\mathrm{kg}$; the linearity coefficient $\left(R^{2}\right)$ was 0.99977 . The detectable limit was $0.05 \mu \mathrm{g} / \mathrm{kg}$. The OTA content was expressed in $\mu \mathrm{g} / \mathrm{kg}$ for solid culture medium and $\mu \mathrm{g} / \mathrm{kg}$ for cocoa beans.

\subsection{Genomic DNA extraction}

Fungal strains were grown in MEA and incubated at $28^{\circ} \mathrm{C}$ for seven days. Spores were transferred to Eppendorf tubes with $0.3 \mathrm{~g}$ of acid-'washed glass beads (Sigma-Aldrich), then tubes were filled until $2 \mathrm{~mL}$ with peptone water $0.1 \%(\mathrm{w} / \mathrm{v})$. DNA extractions were carried out according to the protocol of (El Sheikha 2010). The quantity and purity of DNA extracted were verified by a UV spectrophotometer (Biospec-Nano).

\subsection{PCR amplification reactions and DNA sequencing}

In this study, primers targeting the $\beta$-tubulin gene were used, Tub F (5'- CTC GAG CGT ATG AAC GTC TAC - $3^{\prime}$ ) and Tub R (5'- AAA CCC TGG AGG CAG TCG C- $3^{\prime}$ ) (Sigma, France), which amplify DNA fragments of 340 bp (Bacha et al., 2009; Huy, Mathieu, \& Lebrihi, 2005; Milicevic et al., 2010). The $\beta$-tubulin gene is widely used to distinguish between Aspergillus species (Haas et al. 2013) and other species (Glass and Donaldson 1995).

PCR amplification reactions were performed in a final volume of $50 \mu \mathrm{L}$ containing $5 \mu \mathrm{L}$ of extracted DNA, $0.2 \mathrm{mM}$ of each primer, all the deoxyribonucleotide triphosphate (dNTPs, Promega, France) at $200 \mu \mathrm{M}$, $3.5 \mathrm{mM} \mathrm{MgCl}_{2}, 5 \mu \mathrm{L}$ of $10 \mathrm{x}$ of Top Taq reaction buffer containing $15 \mathrm{mM} \mathrm{MgCl}_{2}$ (Qiagen, France), $1.25 \mathrm{U}$ Top Taq DNA polymerase. The PCR amplification was carried out as follows: initial denaturation at $94^{\circ} \mathrm{C}$ for $3 \mathrm{~min}, 30$ cycles of $94^{\circ} \mathrm{C}$ for $40 \mathrm{~s}, 58^{\circ} \mathrm{C}$ for $40 \mathrm{~s}, 72^{\circ} \mathrm{C}$ for $1 \mathrm{~min}$ and a final extension at $72^{\circ} \mathrm{C}$ for 10 min. Aliquots $(5 \mu \mathrm{l})$ of PCR products were analyzed by electrophoresis in $2 \%(\mathrm{w} / \mathrm{v})$ agarose gel with TAE 1x buffer (40 mM Tris-HCl, pH 7.4, $20 \mathrm{mM}$ sodium acetate, $1.0 \mathrm{mM} \mathrm{Na}_{2}$-EDTA), stained with ethidium bromide in TAE $1 \mathrm{x}$ for $10 \mathrm{~min}$ and rinsed with distilled water for $5 \mathrm{~min}$. Gels were photographed and PCR bands quantified using a standard DNA (100 bp ladder, Promega, France). PCR amplicons were sent for sequencing at GATC Biotech (Germany).

Sequences were compared to the GenBank database using the BLAST program (Altschul et al. 1997) (http://www.ncbi.nlm.nih.gov/BLAST/) submitted to this database.

\section{Results And Discussion}

\subsection{Fungal contamination and infection rate}


A total of 71 fungal strains were isolated, 56 from farm $A$ and 15 from B. Most of the identified fungal strains belonged to Aspergillus and Penicillium genera (Table 1). From farm A, 31 strains belonged to Aspergillus (55.3\%), 21 to Penicillium (37.5\%), and four strains to Cladosporium (7.1\%). In farm B, 11 isolates belonged to Aspergillus (73.3 \%), 2 to Penicillium (13.3\%), and 2 to Cladosporium (13.3 \%) genera. The Aspergillus genus was dominant in both farms, which coincides with reports from other authors (Sánchez-Hervás et al. 2008; Copetti et al. 2011). Regarding the fungal contamination, no uniform distribution was observed in samples from both farms, although they are produced in the same region. This result suggested that fungal distribution (or diversity) is mainly linked to the process than the geography.

Table 1

Occurrence of filamentous fungi isolated from farms A and B.

\begin{tabular}{|lll|}
\hline & Genus & Isolates (\%) \\
\hline Farm A & Aspergillus & $31(55.3)$ \\
& Penicillium & $21(37.5)$ \\
& Cladosporium & $4(7.1)$ \\
\hline \multirow{2}{*}{ Farm B } & Total & $56(100)$ \\
\hline & Aspergillus & $11(73.3)$ \\
& Penicillium & $2(13.3)$ \\
& Cladosporium & $2(13.3)$ \\
\hline & Total & $15(100)$ \\
\hline
\end{tabular}

The number of species detected in each plantation also reflected environmental conditions and differences in the type of cocoa beans processed. In farm A, only Criollo cocoa beans were processed, while in farm B, cocoa beans with different qualities and origins were used. The results also showed that farm A had initial contamination for OTA-producing fungi from the cocoa pod (1.5\% \pm 0.5 ) (Table 2). The samples with the higher ochratoxigenic infection percentage in farm A were those from drying $(78.4 \% \pm$ 13.6) and farm B from storage (37 \% \pm 10.4$)$. Differences in the pulp's biochemical composition influence the presence of microbial populations, such as bacteria and yeast, naturally present during the process (Moreira et al., 2013). Previous studies showed that both lactic acid bacteria (Stiles, 1996; Suzuki et al., 1991) and yeast (Masoud \& Kaltoft, 2006; Masoud et al., 2005) produce organic acids which presents antifungal activity against Aspergillus species. It was also reported that yeast strains Pichia anomala, Pichia kluyveri, and Hanseniaspora uvarum produce considerable quantities of volatile compounds (ethyl acetate, acetate, propionate, and ethyl isoamyl alcohol), which at high concentrations reduce fungal growth (Masoud and Kaltoft 2006). Furthermore, (Spadaro et al., 2004) reported that the mechanisms of 
yeast's antagonistic activity against fungi might be due to adhesion of antagonists cells to mycelia or induced resistance in host tissues. All these parameters could affect the presence of ochratoxigenic species in cocoa from both farms, mainly during fermentation, and therefore play an important role in pulp degradation due to the biochemical reactions and metabolites generated during the fermentation process. These microbial populations may have an antagonistic effect on the OTA-producing fungi infection, affecting the infection percentage during the process.

Table 2

Pod and cocoa beans infection percentages by putative ochratoxigenic fungi at different stages of process.

\begin{tabular}{|llllll|}
\hline \multicolumn{5}{|l|}{ Ochratoxigenic infection (\%) } \\
\hline Farm & Pod Harvested & $\begin{array}{l}\text { Fresh cocoa bean } \\
\text { (before fermentation) }\end{array}$ & Fermentation & Drying & Storage \\
\hline A & $1.5 \pm 0.5$ & $2.1 \pm 2.5$ & $50.3 \pm 7.4$ & $78.4 \pm 13.6$ & $70.3 \pm 3.2$ \\
\hline B & - & $21.8 \pm 2.8$ & $3.4 \pm 3.0$ & $12.7 \pm 5.8$ & $37 \pm 10.4$ \\
\hline
\end{tabular}

During fermentation, the infection by ochratoxigenic fungi were lower in farm B $(3.4 \% \pm 3)$ than in farm $A$ $(50.3 \% \pm 7.4)$. The possible presence of microorganisms with antifungal activity discussed above can influence this point, but fermentation times and air exposure, and surface contact must also be considered.

In farm A, the fermentation process lasted five days, while only three days in farm B. During the last hours of fermentation in farm $A$, the process becomes more aerobic due to partial pulp degradation and, therefore, could allow an increase of OTA-producing fungi infection in grains before day 4 (Fig. 2). Extended fermentation time prolongs beans exposure to air during the "turning" every 24 hours, which is performed by transferring the fermentation mass of one box to another, in which all beans are exposed to the air. This result agrees with the results reported by Hatmi et al. (2015), which showed that regardless of the substrate, a fermentation for five days usually should reduce fungal contamination. However, if the fermenting mass is exposed to aeration, then the contamination level will suffer an increase. In addition, contamination by surface contact was observed. It could be due to either tools or boxes used in both farms. Pulp residues remain attached to the box walls, which are contaminated by previous fermentations and could act as inoculum of ochratoxigenic species. Altogether, these conditions could favor fungal development.

The percentage values of ochratoxigenic infection in farm B were 12.7 \pm 5.8 during drying and $37 \pm 10.4$ in storage, lower than those found in farm $A$. This difference can be attributed to a wash performed at the end of fermentation in farm $B$, which reduces the amount of pulp present in the bean at the beginning of the drying step and therefore the substrate availability for various fungi commonly present during the subsequent stages. A reduction of OTA-producing fungi infection could be appreciated in Fig. 3. In 
contrast, farm A showed a high infection percentage during drying $(78.4 \% \pm 13.6)$ and storage $(70.3 \% \pm$ 3.2). This result coincides with what was observed in the Petri dishes at this stages (Fig. 2) and is in agreement with previous work of Mounjouenpou et al. (2008), who associated an increase in the number of species of filamentous fungi after fermentation with the presence of remains of pulp in the bean.

\subsection{Identification of isolates and OTA-producing ability}

One of the main goals of this study was to isolate and identify the fungal biota representative of the Mexican cocoa process and elucidate potentially OTA-producing fungi. Among the 71 isolated initially strains, 20 were selected as putative ochratoxigenic according to taxonomic keys for common food-borne fungi (Samson et al. 2004). They were considered representative due to their abundance and permanence along all the process. These were identified at the molecular level by sequencing of the $\beta$-tubulin gene. Table 3 shows the molecular identification results and the ability of each strain to produce OTA on MEA medium. 
Table 3

Identification molecular of fungal species associated to cocoa process and OTA producing ability.

Farm Stage Identified specie Percent identity OTA production Accession code

$(\mu \mathrm{g} / \mathrm{kg})$

\begin{tabular}{|c|c|c|c|c|c|}
\hline A & Drying & A. flavus & 100 & ND & МT002446 \\
\hline B & Natural bean & A. carbonarius & 100 & 14307.5 & МT009029 \\
\hline A & Drying & A. westerdijkiae & 99.34 & 2.1 & MT188735 \\
\hline A & Storage & A. amstelodami & 94.06 & ND & MT181963 \\
\hline A & Pod harvested & Penicillium sp. & 100 & 8495.2 & MT188736 \\
\hline A & Drying & A. westerdijkiae & 99.7 & 417.4 & MT188737 \\
\hline A & Drying & A. steynii & 100 & 1482.2 & MT193645 \\
\hline A & Storage & C. halotolerans & 100 & ND & MT199513 \\
\hline A & Storage & A. europaeus & 99.67 & ND & MT199514 \\
\hline B & Drying & A. amstelodami & 93.98 & ND & MT199515 \\
\hline A & Storage & Penicillium sp. & 99.68 & ND & MT211966 \\
\hline A & Drying & Penicillium sp. & 99.69 & ND & MT211967 \\
\hline A & Natural bean & Penicillium sp. & 89.78 & ND & MT211965 \\
\hline A & Pod harvested & Penicillium sp. & 90.12 & 6364.3 & MT350494 \\
\hline A & Storage & Penicillium sp. & 90.12 & 5933.4 & MT350495 \\
\hline A & Natural bean & A. giganteus & 98.75 & ND & MT350496 \\
\hline A & Drying & A. heteromorphus & 99.57 & ND & MT362703 \\
\hline A & Drying & Penicillium sp. & 99.4 & ND & MT362700 \\
\hline A & Storage & A. tamarii & 100 & ND & MT362701 \\
\hline A & Storage & A. niger & 100 & ND & МT362702 \\
\hline
\end{tabular}

In farm A, a great diversity of species was observed, such as Aspergillus flavus, Aspergillus westerdijkiae, Aspergillus steyni, Aspergillus amstelodami, Aspergillus europaeus, Aspergillus heteromorphus, Aspergillus niger, Aspergillus giganteus, and Aspergillus tamarii. However, only Aspergillus westerdijkiae and $A$. steynii were detected as high OTA producers $(417.4 \mu \mathrm{g} / \mathrm{kg}$ and $1482.2 \mu \mathrm{g} / \mathrm{kg}$, respectively), which A. steynii showed the highest OTA-producing ability. Currently, A. westerdijkiae is considered the main 
OTA-producing species in tropical areas (Marino et al., 2009). However, a study by Gil-Serna et al., (2011) showed that while $A$. westerdijkiae shows a high OTA production capacity, A. steynii (Frisvad \& Frank 2004) must be considered the most significant risk of contamination. Though, the rest of OTA producing species belonging to this section should not be ignored.

Another interesting strain was $A$. giganteus, which was isolated from fresh natural beans before fermentation. This species has been reported as a producer of an antifungal protein (AFP) with a low molecular weight. This protein effectively restricts the growth of significant human- and plant-pathogenic filamentous fungi (Hagen et al., 2007). Based on their degrees of susceptibility to AFP, filamentous fungi are classified into sensitive (e.g., Aspergillus fumigatus, Aspergillus niger, Fusarium oxysporum, and Fusarium moniliforme), moderately sensitive (e.g., Aspergillus nidulans), and resistant species (e.g., Penicillium chrysogenum). The growth-inhibitory effect of AFP has been associated with the permeabilization of the fungal membranes (Theis et al. 2003). Interestingly, Aspergillus giganteus could play an important role in the inhibition of certain fungi along and fermentation and subsequent stages, and therefore, it is the first time A. giganteus is reported in cocoa beans.

Some strains identified as Penicillium sp. with no OTA production were observed at the fermentation, drying, and storage steps in both farms (Figs. 2 and 3). It could be a guide to think that these species are intimately related to the fermentation stage despite the type of process or region considered.

Importantly, Penicillium sp. species were isolated from pods harvested from farm A and showed a high OTA-producing ability $(8495.2 \mu \mathrm{g} / \mathrm{kg})$. They also exhibited a different identification profile compared to the other two Penicillium sp. identified from the same process. It was the only one with 100 percent identity (MT188736), while the other Penicillium sp. isolates identified as high OTA-producers showed the same 90.12 percent identity (MT350494 and MT350495). This pair of Penicillium isolates also showed close similarities in OTA-producing ability even when they come from different stages of the process; pod harvested $(6364.4 \mu \mathrm{g} / \mathrm{kg})$ and storage $(5933.4 \mu \mathrm{g} / \mathrm{kg})$. It is possible that this species remained during all stages, from harvest to storage, in a sporulated form, and germinated again upon optimal conditions during storage. It reinforced the convenience of a wash after the fermentation stage to reduce contamination levels in subsequent stages.

In farm B, the main OTA-producing species was Aspergillus carbonarius $(14307.5 \mu \mathrm{g} / \mathrm{kg})$ isolated from fresh cocoa beans (unfermented), which can grow up and produce OTA in a wide range of water activity $(\mathrm{Aw})$, at low and high temperatures (Esteban et al., 2006). No other strain was observed at this stage (Fig. 3), so the percentage of infection in fresh cocoa beans $(21.8 \pm 3.7)$ could be attributed to the presence of these species. The presence of $A$. carbonarius as the main OTA-producer and the absence of another species may be due to their black spores, which protect from sunlight and UV light, giving a competitive advantage over other species (Pitt and Hocking 1997; Taniwaki et al. 2018). It supports the importance of $A$. carbonarius as the main source of OTA in cocoa beans. It coincides with the study carried out by Mounjouenpou et al. (2008), which associated unfermented beans with the presence of damaged pods and delays between harvest and pod opening, similar characteristics to those presented in 
farm B. Also, Kedjebo et al., in 2016, recommend the use of healthy pods for the fermentation process and avoid the storage of damaged cocoa pods for a period greater than four days. Aspergillus carbonarius was also reported as the main source of OTA in other food matrices, such as grapes and its derivatives (Abarca et al., 2003) and coffee (Coffea canephora) (Joosten et al., 2001).

\subsection{OTA content in cocoa beans}

It has been reported that OTA is mainly found in the cocoa shell (Raters and Matissek 2007), but in this studio, OTA analyses were performed with the whole cocoa bean, namely, the cocoa shell and cocoa kernel. OTA contents on cocoa beans collected from farm A and B at different stages of the process and OTA-producing fungi associated are shown in Table 4.

Table 4

OTA content in cocoa beans and its relation with OTA-producing and nonproducing fungi in post-harvest stages.

\begin{tabular}{|c|c|c|c|c|}
\hline \multirow{2}{*}{ Stages } & \multicolumn{2}{|c|}{ OTA concentration $(\mu \mathrm{g} / \mathrm{kg})$} & \multicolumn{2}{|c|}{ Identified OTA producing species } \\
\hline & Farm A & Farm B & Farm A & Farm B \\
\hline \multirow[t]{2}{*}{ Natural Bean } & $1.3 \pm 0.3$ & $22.2 \pm 3.5$ & Penicillium sp. & A. carbonarius* \\
\hline & & & A. giganteus & \\
\hline Fermentation & $3.9 \pm 0.5$ & $4.4 \pm 0.3$ & Penicillium sp. & Penicillium sp. \\
\hline \multirow[t]{8}{*}{ Drying } & $10.4 \pm 1.2$ & $1.5 \pm 0.8$ & A. westerdijkiae* & Penicillium sp. \\
\hline & & & A. westerdijkiae* & \\
\hline & & & A. steynii* & \\
\hline & & & A. flavus & \\
\hline & & & A. amstelodami & \\
\hline & & & Penicillium sp. & \\
\hline & & & Penicillium sp. * & \\
\hline & & & A. heteromorphus & \\
\hline \multirow[t]{6}{*}{ Storage } & $304.6 \pm 15.3$ & $11.3 \pm 0.5$ & Penicillium sp. & Penicillium sp. \\
\hline & & & Penicillium sp. * & \\
\hline & & & A. niger & \\
\hline & & & A. tamarii & \\
\hline & & & C. halotolerans & \\
\hline & & & A. europaeus & \\
\hline
\end{tabular}


A considerable amount of OTA was observed in samples of fresh cocoa beans $(22.2 \pm 3.5 \mu \mathrm{g} / \mathrm{kg})$ on farm B. This content may be associated with the presence of $A$. carbonarius, the main OTA-producing species, and the use of damaged pods. In contrast, in farm A, fresh cocoa beans present a maximum OTA content of $1.3 \pm 0.3 \mu \mathrm{g} / \mathrm{kg}$, and no species with a high ability to produce OTA was detected. It may be due to the good quality of the pods used and a shorter pod opening delay (before $48 \mathrm{~h}$ ), and therefore, it is in agreement with the results obtained by Mounjouenpou et al. (2012), describing a good correlation between OTA presence in the cocoa beans from bad quality pods and isolated toxigenic strains.

Concerning the fermentation, the maximum OTA content observed in farm A was $3.9 \pm 0.5 \mu \mathrm{g} / \mathrm{kg}$, while in farm B was $4.4 \pm 0.3 \mu \mathrm{g} / \mathrm{kg}$. These values showed a relation with the percentage of ochratoxigenic infection at this stage. OTA levels were lower during fermentation than drying and storage steps. It may be due to the presence of microorganisms naturally present in fermentation, such as lactic acid bacteria, acetic acid bacteria (Camu et al. 2007), and yeasts (Jespersen et al., 2005; Nielsen et al., 2005), which can generate metabolites that inhibit the development of ochratoxigenic fungi and therefore OTA production. According to the observations by (Copetti et al. 2012), the presence and action of weak organic acids, especially acetic acid, on ochratoxigenic fungi at low $\mathrm{pH}$, have an important role in OTA accumulation in cocoa and suggest that fermentation practices conducted for the enhancement of acetic acid could minimize the problem of OTA contamination in cocoa.

In farm A, on dry $(10.4 \pm 1.2 \mu \mathrm{g} / \mathrm{kg})$ and stored $(304.6 \pm 15.3 \mu \mathrm{g} / \mathrm{kg})$ cocoa bean samples, high levels of OTA contents were measured. This result agrees with a study carried out by Copetti et al. (2010)' which found that the drying step is one of the critical stages to contamination by OTA-producing fungi and OTA. During drying, the beans start losing water. Therefore there is a decrease in Aw values, restricting the development of the competitive microbiota due to the high sensitivity of bacteria and yeast at low water availability, but there is still enough water to sustain fungal development (Beuchat 1987). On the other hand, extended periods of storage combined with the presence of highly toxigenic species resulted in the highest content of OTA in cocoa beans found in farm A $(304.6 \mu \mathrm{g} / \mathrm{kg})$, this concentration was measured on the whole grain. However, it has been reported that OTA is mainly found in the cocoa shell (Raters and Matissek 2005). Since cocoa is mainly consumed without the shell, so the OTA content consumed is probably lower. It is in agreement with other studies, in which the storage is stated as one of the most critical stages in the process of cacao concerning the presence of highly toxigenic species (Amézqueta et al. 2008; Copetti et al. 2010).

However, low values were observed in dry $(1.5 \pm 0.8 \mu \mathrm{g} / \mathrm{kg})$ and storage $(11.3 \pm 0.5 \mu \mathrm{g} / \mathrm{kg})$ cocoa beans samples from farm B. As previously discussed, introducing a washing step of cocoa beans at the end of the fermentation as in farm $B$ is desirable since it reduces pulp (available substrate), then the presence of highly ochratoxigenic species. Therefore, the risk of contamination by OTA in cocoa beans could also be reduced in subsequent stages of drying and storage.

\section{Conclusions}


Our findings showed that during the cocoa process, drying and storage are stages with higher risks of contamination by OTA due to the development of associated OTA-producing fungi. Nevertheless, washing cocoa beans immediately after the fermentation removes the pulp (available substrate) and could reduce infection and thus the risk of contamination during the subsequent stages. Poor quality cocoa pods and an extended delay between harvest and pod opening can trigger early OTA contamination in fresh cocoa beans. Therefore, pod opening is a critical stage for OTA contamination.

Monitoring OTA contamination during every single stage in the cocoa beans process in México could help implement a hazard analysis and critical control point (HACCP) system and then minimize the food chain risk.

This study is the first report about the occurrence of OTA in cocoa beans from Mexico. These results could be a guideline for producers to improve post-harvest treatments to prevent OTA contamination and therefore enhance the sanitary quality of Mexican cocoa beans. Moreover, subsequent studies should focus on OTA and fungal contamination in cocoa beans from critical stages, as mentioned above. It together could help to define standards for a high-quality cocoa beans production and to establish the basis for a possible regulation in Mexico, as well as develop new opportunities for exportation.

\section{Declarations}

\section{Acknowledgments}

Elena I. Champion-Martínez was supported by a Ph.D. grant from CONACyTand a DESI grant from CIRAD.

\section{Conflict of interest statement}

The authors declare no conflict of interest.

\section{Authors and Contributors}

Champion-Martínez E.l: formal analysis, writing original draft, Durand Noël: methodology, supervision, Meile J.C: methodology, review \& editing, González-Ríos 0: conceptualization, funding acquisition, Fernández F.J: data interpretation, Alter P: methodology, formal analysis, Montet D: supervision, funding adquisition, Suárez-Quiroz M.L: conceptualization, funding adquisition, review \& editing.

\section{References}

Abarca ML, Accensi F, Bragulat MR, et al (2003) Aspergillus carbonarius as the main source of ochratoxin A contamination in dried vine fruits from the Spanish market. J Food Prot 66:504-506

Abrunhosa L, Paterson RRM, Kozakiewicz Z, et al (2001) Mycotoxin production from fungi isolated from grapes RID. Lett Appl Microbiol 32:240-242. https://doi.org/10.1046/j.1472-765X.2001.00897.x 
Afoakwa EO (2010) Chocolate Science and Technology. Oxford, UK

Altschul SF, Madden TL, Schäffer AA, et al (1997) Gapped BLAST and PS I-BLAST: a new generation of protein database search programs. Nucleic Acids Res 25:3389-3402.

https://doi.org/10.1093/nar/25.17.3389

Amézqueta S, González-Peñas E, Dachoupakan C, et al (2008) OTA-producing fungi isolated from stored cocoa beans. Lett Appl Microbiol 47:197-201. https://doi.org/10.1111/j.1472-765X.2008.02409.x

Bacha N, Atoui A, Mathieu F, et al (2009) Aspergillus westerdijkiae polyketide synthase gene "aoks1" is involved in the biosynthesis of ochratoxin A. Fungal Genet Biol.

https://doi.org/10.1016/j.fgb.2008.09.015

Beuchat LR (1987) Influence of water activity on sporulation, germination, outgrowth, and toxin production. In: L.D. Rockland, L.R. Beuchat (eds) Water Activity: Theory and Applications to Food. Marcel Dekker, New York, pp 153-172

Biehl B, Ziegleder G (2003) Cocoa: Chemistry of processing. Encycl. food Sci. Nutr. 1436-1448

Bonvehí JS (2004) Occurrence of ochratoxin A in cocoa products and chocolate. J Agric Food Chem 52:6347-6352. https://doi.org/10.1021/jf040153w

Bragulat MR, Abarca ML, Cabañes FJ (2001) An easy screening method for fungi producing ochratoxin A in pure culture. Int J Food Microbiol 71:139-144. https://doi.org/10.1016/S0168-1605(01)00581-5

CAC-Codex Alimentarius Commission (2008) Discussion Paper on Ochratoxin a in Cocoa. In: Jt. FAO/WHO Food Stand. Program. codex commitee Contam. foods, Discuss. Pap. ochratoxin A cocoa. http://www.fao.org/tempref/codex/Meetings/CCCF/cccf2/cf02_15e.pdf

Camu N, De Winter T, Verbrugghe K, et al (2007) Dynamics and biodiversity of populations of lactic acid bacteria and acetic acid bacteria involved in spontaneous heap fermentation of cocoa beans in Ghana. Appl Environ Microbiol 73:1809-1824. https://doi.org/10.1128/AEM.02189-06

Copetti M V., lamanaka BT, Frisvad JC, et al (2011) Mycobiota of cocoa: From farm to chocolate. Food Microbiol 28:1499-1504. https://doi.org/10.1016/j.fm.2011.08.005

Copetti M V, lamanaka BT, Mororó RC, et al (2012) The effect of cocoa fermentation and weak organic acids on growth and ochratoxin A production by Aspergillus species. Int J Food Microbiol 155:158-164. https://doi.org/10.1016/j.ijfoodmicro.2012.01.026

Copetti M V, Pereira JL, lamanaka BT, et al (2010) Ochratoxigenic fungi and ochratoxin A in cocoa during farm processing. Int J Food Microbiol 143:67-70. https://doi.org/10.1016/j.ijfoodmicro.2010.07.031 
El Sheikha AF (2010) Determination of geographical origin of Shea tree and Physalis fruits by using the genetic fingerprints of the microbial community by PCR/DGGE. Analysis of biological properties of some fruit extracts. Montpellier University II

Esteban A, Abarca ML, Bragulat MR, Cabañes FJ (2006) Study of the effect of water activity and temperature on ochratoxin A production by Aspergillus carbonarius. Food Microbiol 23:634-640. https://doi.org/10.1016/j.fm.2005.12.006

Frisvad J, Frank J (2004) New ochratoxin A producing species of Aspergillus section Circumdati. Stud Mycol 23-43

Gil-Serna J, Vázquez C, Sardiñas N, et al (2011) Revision of ochratoxin a production capacity by the main species of Aspergillus section Circumdati . Aspergillus steynii revealed as the main risk of OTA contamination. Food Control 22:343-345. https://doi.org/10.1016/j.foodcont.2010.06.018

Glass NL, Donaldson GC (1995) Development of primer sets designed for use with the PCR to amplify conserved genes from filamentous ascomycetes. Appl Environ Microbiol 61:1323-1330

Gonzalez VW, Amaya G para el DI de EU (USAID) (2005) Cacao en Mexico: Competitividad y Medio Ambiente con Alianzas

Haas D, Pfeifer B, Reiterich C, et al (2013) Identification and quantification of fungi and mycotoxins from Pu-erh tea. Int J Food Microbiol 166:316-322. https://doi.org/10.1016/j.ijfoodmicro.2013.07.024

Hagen S, Marx F, Ram AF, Meyer V (2007) The antifungal protein AFP from Aspergillus giganteus inhibits chitin synthesis in sensitive fungi. Appl Environ Microbiol 73:2128-2134.

https://doi.org/10.1128/AEM.02497-06

Hatmi RU, Kobarsih M, Cahyaningrum N (2015) ScienceDirect Fungi Level Analysis of Cocoa Beans Based on Fermentation Box Type and Duration. Procedia Food Sci 3:371-382. https://doi.org/10.1016/j.profoo.2015.01.041

Hocking AD, Pitt JI (1980) Dichloran-glycerol medium for enumeration of xerophilic fungi from lowmoisture foods. Appl Environ Microbiol 39:488-492

Höhler D (1998) Ochratoxin A in food and feed: occurrence, legislation and mode of action. Z Ernahrungswiss 37:2-12.

Hussein H., Brasel J. (2001) Toxicity, metabolism and impact of mycotoxins on human and animals. Toxicology, 167:101-134. https://doi.org/http://dx.doi.org/10.1016/S0300-483X(01)00471-1

Huy PD, Mathieu F, Lebrihi A (2005) Two primer pairs to detect OTA producers by PCR method. Int J Food Microbiol 104:61-67. https://doi.org/10.1016/j.ijfoodmicro.2005.02.004 
ICA (2011) International Cocoa Awards. http://www.cocoaofexcellence.org/index.php? option=com_content\&view=article\&id=73\&ltemid=63. Accessed 24 May 2016

ICA (2019) Results of the 2019 Edition. Results 2019 Ed 1-56

International Agency for Research on Cancer (1993) Ochratoxin A. IARC Monogr Eval Carcinog Risk Chem to Humans 56:489-521

Jespersen L, Nielsen DS, Hønholt S, Jakobsen M (2005) Occurrence and diversity of yeasts involved in fermentation of West African cocoa beans. FEMS Yeast Res 5:441-453.

https://doi.org/10.1016/j.femsyr.2004.11.002

Joosten HML., Goetz J, Pittet A, et al (2001) Production of ochratoxin A by Aspergillus carbonarius on coffee cherries. Int J Food Microbiol 65:39-44. https://doi.org/10.1016/S0168-1605(00)00506-7

Kedjebo KBD, Guehi TS, Kouakou B, et al (2016) Effect of post-harvest treatments on the occurrence of ochratoxin A in raw cocoa beans. Food Addit Contam Part A 33:157-166.

https://doi.org/10.1080/19440049.2015.1112038

Maaroufi K, Achour A, Betbeder AM, et al (1995) Foodstuffs and human blood contamination by the mycotoxin ochratoxin A: correlation with chronic interstitial nephropathy in Tunisia. Arch Toxicol 69:552558. https://doi.org/10.1007/s002040050211

Magan N, Aldred D (2005) Conditions of formation of ochratoxin A in drying, transport and in different commodities. Food AdditContam 22:10-16. https://doi.org/10.1080/02652030500412154

Marino A, Nostro A, Fiorentino C (2009) Ochratoxin A production by Aspergillus westerdijkiae in orange fruit and juice. Int J Food Microbiol 132:185-189. https://doi.org/10.1016/j.ijfoodmicro.2009.03.026

Masoud W, Kaltoft $\mathrm{CH}$ (2006) The effects of yeasts involved in the fermentation of Coffea arabica in East Africa on growth and ochratoxin A (OTA) production by Aspergillus ochraceus. Int J Food Microbiol 106:229-34. https://doi.org/10.1016/j.ijfoodmicro.2005.06.015

Masoud W, Poll L, Jakobsen M (2005) Influence of volatile compounds produced by yeasts predominant during processing of Coffea arabica in East Africa on growth and ochratoxin A (OTA) production by Aspergillus ochraceus. Yeast 22:1133-1142. https://doi.org/10.1002/yea.1304

Milicevic D, Nikšic M, Baltić T, et al (2010) A survey of occurrence of toxogenic fungi and mycotoxins in pig feed samples-use in evaluation of risk assessment. Vet World 3:305-311.

https://doi.org/10.5455/vetworld.2010.305-311

Moreira IM da V, Miguel MG da CP, Duarte WF, et al (2013) Microbial succession and the dynamics of metabolites and sugars during the fermentation of three different cocoa (Theobroma cacao L.) hybrids. Food Res Int 54:9-17. https://doi.org/10.1016/j.foodres.2013.06.001 
Mounjouenpou P, Gueule D, Fontana-Tachon A, et al (2008) Filamentous fungi producing ochratoxin a during cocoa processing in Cameroon. Int J Food Microbiol 121:234-241.

https://doi.org/10.1016/j.ijfoodmicro.2007.11.017

Mounjouenpou P, Gueule D, Guyot B (2012) Incidence of Pod Integrity on the Fungal Microflora and Ochratoxin-A Production in Cocoa. J Biol Life Sci 3:. https://doi.org/10.5296/jbls.v3i1.2231

Nakajima M, Tsubouchi H, Miyabe M, Ueno Y (1997) Survey of aflatoxin B1 and ochratoxin a in commercial green coffee beans by high-performance liquid chromatography linked with immunoaffinity chromatography. Food Agric Immunol 9:77-83. https://doi.org/10.1080/09540109709354938

Nielsen DS, Hønholt S, Tano-Debrah K, Jespersen L (2005) Yeast populations associated with Ghanaian cocoa fermentations analysed using denaturing gradient gel electrophoresis (DGGE). Yeast 22:271-284. https://doi.org/10.1002/yea.1207

O'Callaghan J, Caddick MX, Dobson ADW (2003) A polyketide synthase gene required for ochratoxin A biosynthesis in Aspergillus ochraceus. Microbiology 149:3485-3491.

https://doi.org/10.1099/mic.0.26619-0

Pfohl-Leszkowicz A, Manderville RA (2007) Ochratoxin A: An overview on toxicity and carcinogenicity in animals and humans. Mol Nutr Food Res 51:61-99. https://doi.org/10.1002/mnfr.200600137

Pitt Jl (2000) Toxigenic fungi and mycotoxins. 56:184-192

Pitt Jl, Hocking AD (1997) Fungi and Food Spoilage, 2nd edn. Blackie Academic \& Professional, London Raters M, Matissek R (2007) New examinations of mycotoxin carryover to cocoa beans. Mycotoxin Res 23:39-42. https://doi.org/10.1007/BF02946023

Raters M, Matissek R (2005) Study on distribution of mycotoxins in cocoa beans. Mycotoxin Res 21:182186. https://doi.org/10.1007/BF02959259

Samson RA, Hoekstra ES, Frisvad JC (2004) Introduction to food-and airborne fungi, 7th edn. Utrecht, The Netherlands

Sánchez-Hervás M, Gil J V., Bisbal F, et al (2008) Mycobiota and mycotoxin producing fungi from cocoa beans. Int J Food Microbiol 125:336-340. https://doi.org/10.1016/j.ijfoodmicro.2008.04.021

SIAP/SAGARPA (2018) Atlas 2012-2018. Serv Inf Agroaliment y Pesq Publicaciones SIAP. https://doi.org/https://nube.siap.gob.mx/gobmx_publicaciones_siap/pag/2018/Atlas-Agroalimentario2018

Spadaro D, Garibaldi A, Gullino ML (2004) Control of Penicillium expansum and Botrytis cinerea on apple combining a biocontrol agent with hot water dipping and acibenzolar-S-methyl, baking soda, or ethanol 
application. Postharvest Biol Technol 33:141-151. https://doi.org/10.1016/j.postharvbio.2004.02.002

Stiles ME (1996) Biopreservation by lactic acid bacteria. Antonie Van Leeuwenhoek 70:331-345. https://doi.org/10.1007/BF00395940

Stoev SD (1998) The role of ochratoxin A as a possible cause of Balkan endemic nephropathy and its risk evaluation. Vet Hum Toxicol 40:352-360

Suárez-Quiroz M, González-Rios O, Barel M, et al (2004) Study of ochratoxin A-producing strains in coffee processing. Int J Food Sci Technol 39:501-507. https://doi.org/10.1111/j.1365-2621.2004.00810.x

Suzuki I, Nomura M, Morichi T (1991) Isolation of lactic acid bacteria which suppress mold growth and show antifungal action. Milchwissenschaft 46:635-639

Tafuri A, Ferracane R, Ritieni A (2004) Ochratoxin A in Italian marketed cocoa products. Food Chem 88:487-494. https://doi.org/10.1016/j.foodchem.2004.01.061

Taniwaki MH, Pitt Jl, Magan N (2018) Aspergillus species and mycotoxins: occurrence and importance in major food commodities. Curr Opin Food Sci 23:38-43. https://doi.org/10.1016/j.cofs.2018.05.008

Teixeira J, Magalhães D, Andrade G, et al (2011) Occurrence of Ochratoxin A in Brazilian cocoa beans. Food Control 22:744-748. https://doi.org/10.1016/j.foodcont.2010.11.006

Theis T, Wedde M, Meyer V, Stahl U (2003) The Antifungal Protein from Aspergillus giganteus Causes Membrane Permeabilization The Antifungal Protein from Aspergillus giganteus Causes Membrane Permeabilization. Antimicrob Agents Chemother 47:588-593. https://doi.org/10.1128/AAC.47.2.588

Thompson SS, Miller KB, Lopez AS (2001) Cocoa and coffee. In: Doyle MP, Beuchat LR, Montville TJ (eds) Food Microbiology Fundamentals and Frontiers. ASM, Press., Washington, D.C., pp 721-736

Turcotte AM, Scott PM, Tague B (2013) Analysis of cocoa products for ochratoxin A and aflatoxins. Mycotoxin Res 29:193-201. https://doi.org/10.1007/s12550-013-0167-x

Varga J, Kevei E, Rinyu E, et al (1996) Ochratoxin production by Aspergillus species. Appl Env Microbiol 62:4461-4464

Woo C, El-Nezami H (2016) Maternal-Fetal Cancer Risk Assessment of Ochratoxin A during Pregnancy. Toxins (Basel) 8:87. https://doi.org/10.3390/toxins8040087

Zain ME (2011) Impact of mycotoxins on humans and animals. J Saudi Chem Soc 15:129-144. https://doi.org/10.1016/j.jscs.2010.06.006

\section{Figures}




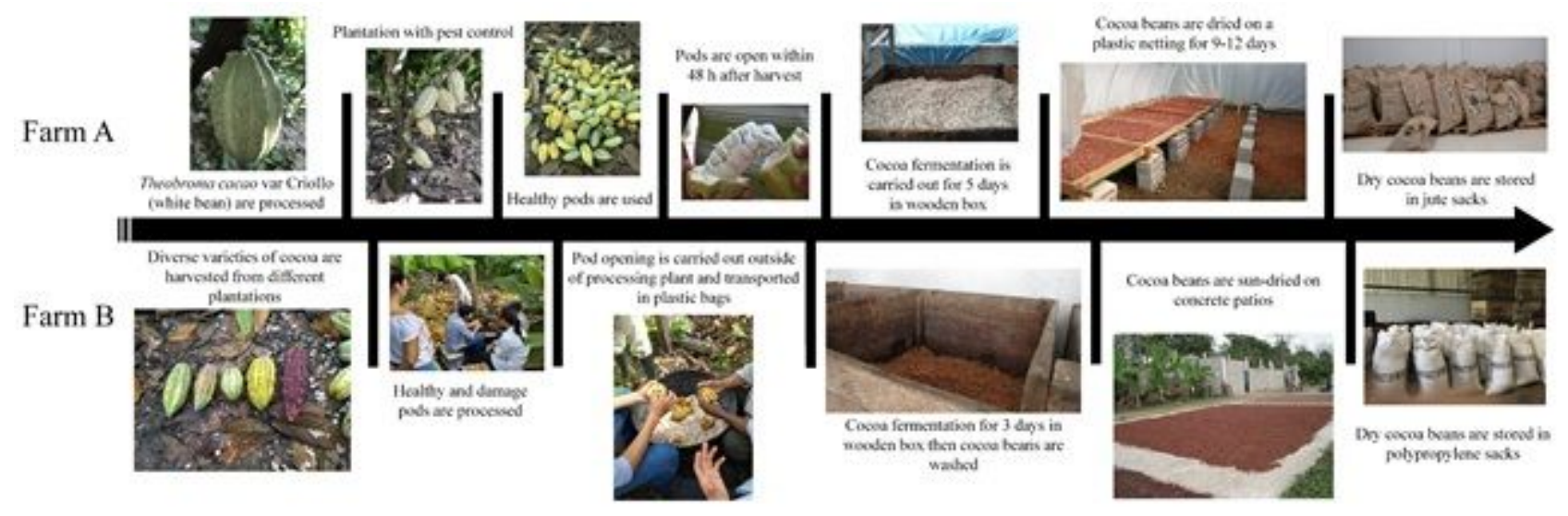

Figure 1

Post-harvest process of cocoa beans from Mexican farms
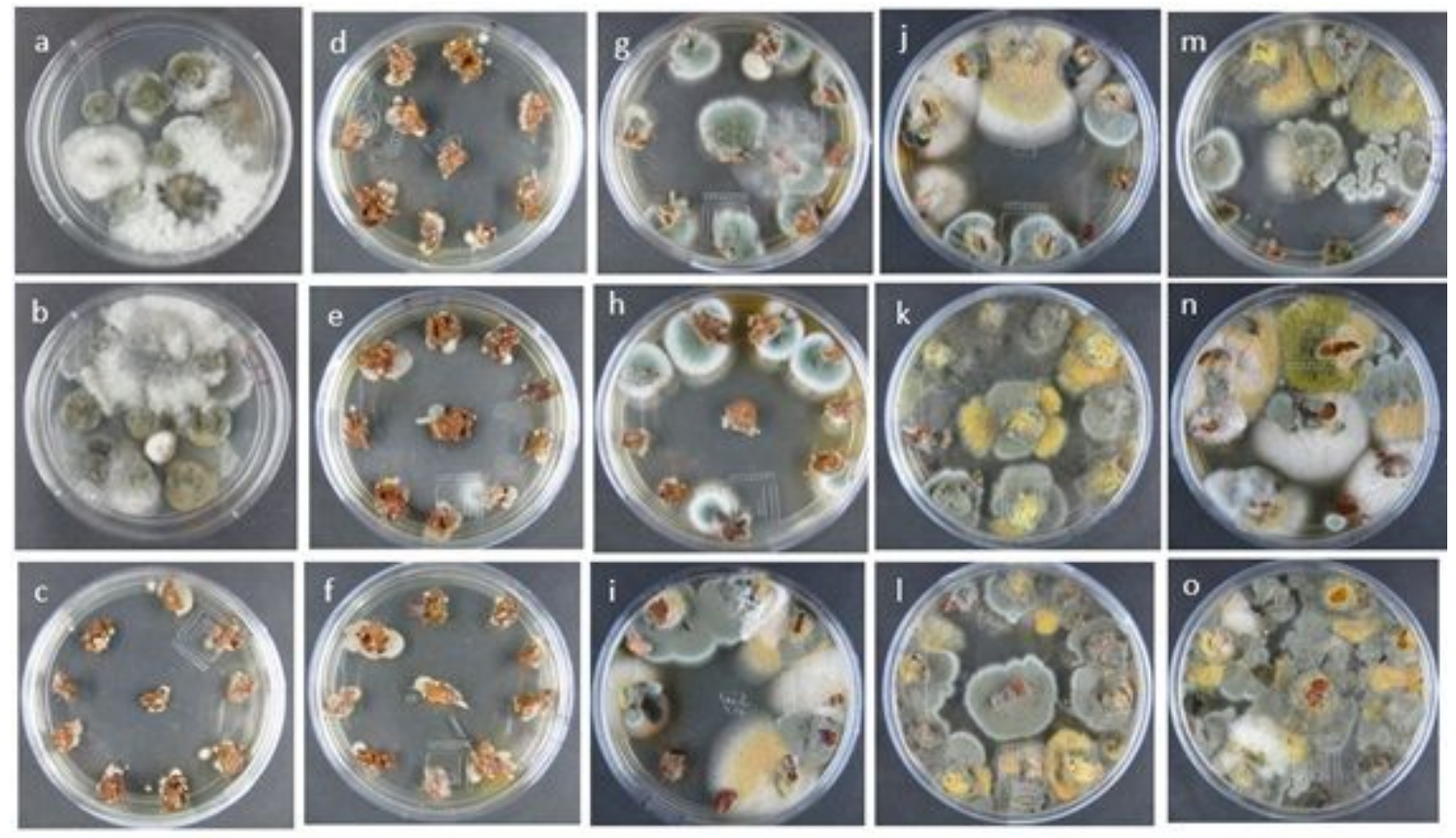

Figure 2

OTA-producing fungi infection in farm A: a) Pod in tree; b) Pod harvested; c) Natural bean, fermentation:

d) 1 day; e) 2 days; f) 3 days; g) 4 days; h) 5 days; Drying: i) 0 days; j) 3 days; k) 6 days; I) 9 days; Storage:

m) 7 days; n) 21 days; o) 30 days. 


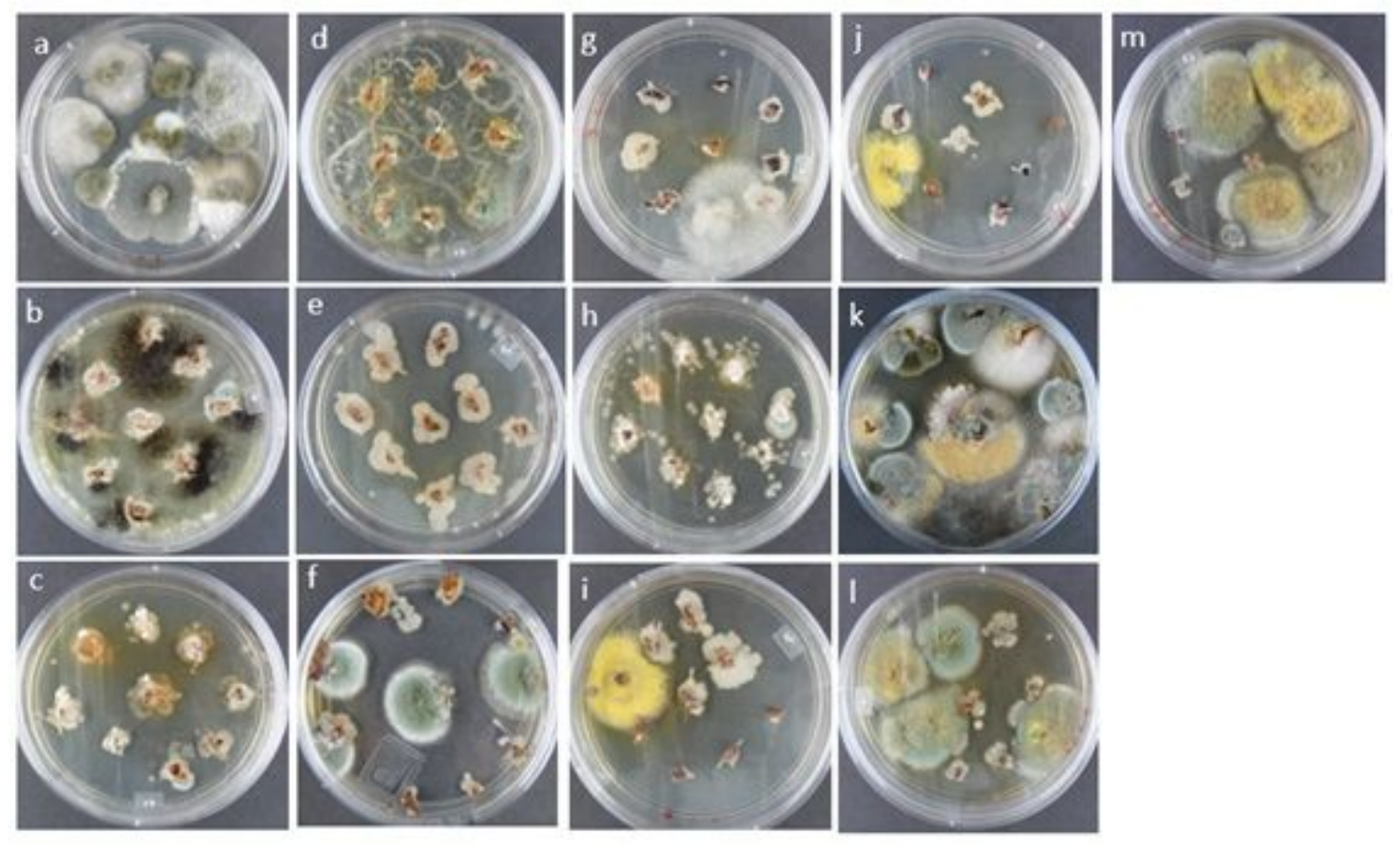

Figure 3

OTA-producing fungi infection in farm B: a) Pod in tree; b) Natural bean fermentation: c) 0 days; d) 1 days; e) 2 days; f) 3 days; Dring: g) 0 days; h) 1 days; i) 2 days; j) 3 days; k) 4 days; Storage: I) 7 days; m) 30 days. 